CSR in the Middle East 
Also by Dima Jamali and Yusuf Sidani

MANAGEMENT: ARAB WORLD EDITION (co-edited with S.P. Robbins and M. Coulter) 


\section{CSR in the Middle East}

\section{Fresh Perspectives}

Edited by

Dima Jamali and Yusuf Sidani

American University of Beirut

palgrave
macmillan 


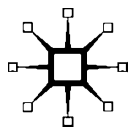

Selection and editorial content $\odot$ Dima Jamali and Yusuf Sidani 2012 Individual chapters $@$ the contributors 2012

Softcover reprint of the hardcover 1st edition 2012 978-0-230-34821-9

All rights reserved. No reproduction, copy or transmission of this publication may be made without written permission.

No portion of this publication may be reproduced, copied or transmitted save with written permission or in accordance with the provisions of the Copyright, Designs and Patents Act 1988, or under the terms of any licence permitting limited copying issued by the Copyright Licensing Agency, Saffron House, 6-10 Kirby Street, London EC1N 8TS.

Any person who does any unauthorized act in relation to this publication may be liable to criminal prosecution and civil claims for damages.

The authors have asserted their rights to be identified as the authors of this work in accordance with the Copyright, Designs and Patents Act 1988.

First published 2012 by

PALGRAVE MACMILLAN

Palgrave Macmillan in the UK is an imprint of Macmillan Publishers Limited, registered in England, company number 785998, of Houndmills, Basingstoke, Hampshire RG21 6XS.

Palgrave Macmillan in the US is a division of St Martin's Press LLC, 175 Fifth Avenue, New York, NY 10010.

Palgrave Macmillan is the global academic imprint of the above companies and has companies and representatives throughout the world.

Palgrave ${ }^{\circledR}$ and Macmillan ${ }^{\circledR}$ are registered trademarks in the United States, the United Kingdom, Europe and other countries.

ISBN 978-1-349-34541-0

ISBN 978-1-137-26620-0 (eBook)

DOI $10.1057 / 9781137266200$

This book is printed on paper suitable for recycling and made from fully managed and sustained forest sources. Logging, pulping and manufacturing processes are expected to conform to the environmental regulations of the country of origin.

A catalogue record for this book is available from the British Library.

A catalog record for this book is available from the Library of Congress.

$\begin{array}{llllllllll}10 & 9 & 8 & 7 & 6 & 5 & 4 & 3 & 2 & 1\end{array}$

$\begin{array}{llllllllll}21 & 20 & 19 & 18 & 17 & 16 & 15 & 14 & 13 & 12\end{array}$ 
This book is dedicated to our fellow citizens of the Middle East, with the hope that it will inspire further engagement in corporate social responsibility here and abroad 
This page intentionally left blank 


\section{Contents}

List of Illustrations ix

Acknowledgments $\quad$ xi

Notes on Contributors xiii

List of Abbreviations and Acronyms $\quad \mathrm{xxi}$

Introduction: CSR in the Middle East:

Fresh Perspectives

Dima Jamali and Yusuf Sidani

1 CSR and Philanthropy: Different Forms of Effective Social Investment

Sari Kassis and Yazan Majaj

2 Harnessing Values for Impact Beyond Profit in MENA

David L. Haskell, Janice Hayashi Haskell

and Jessica Jinju Pottenger

3 CSR to Increase Access to Medicines: Lessons and Opportunities for the Middle East Joseph Antoun

4 CSR: A Cost or an Opportunity for SMEs in the Middle East?

Dima Jamali and Alexandra Tarazi

5 Socially Responsible Employee Management: Case Studies from Saudi Arabia and Lebanon

Marian Eabrasu and Akram Al Ariss

6 Corporate Environmental Responsibility in Jordan: The Potential and Limits

Muna Y. Hindiyeh, Malyuba Abu-Daabes

and Haitham E. Salti 
viii Contents

7 The Development of CSR Reporting in the Middle East Jeannette Vinke and Aida El-Khatib

8 The AUB Neighborhood Initiative: Social Responsibility in a University's Backyard

Tonnie Choueiri and Cynthia Myntti

Conclusions and the Future

Dima Jamali

Index 


\section{Illustrations}

\section{Tables}

3.1 Risks and Benefits of CSR Strategies to Increase Access to Medicines

4.1 Strengths of SMEs in Relation to CSR

4.2 Challenges of SMEs in Relation to CSR 79

4.3 Company Description $\quad 82$

6.1 Matrix of Key CSR Issues with Appropriate Indicators by Stakeholders

6.2 Sources of Emissions in Jordan

6.3 Most Feasible Clean Production Options for Plant A 125

6.4 Most Feasible Clean Production Options for Plant B 125

7.1 International CSR Reporting Standards and Frameworks

7.2 Interviewee Information 144

8.1 Organizations as Place Builders 172

\section{Figures}

2.1 The Social Impact of Care with Love 30

2.2 The Sustainable Profitability of Care with Love 31

2.3 The Care with Love Values Assimilation Process 31

2.4 Improvement of Average Caregiver Performance 35

2.5 Acceleration of Excellent Caregiver Performance 36

2.6 Self-Reported Caregiver Motivation Rankings 37

2.7 Value Exchange of Respect and Love 43

3.1 Treatment Affordability for Adult Respiratory Infection $\quad 54$

7.1 Sustainability Decision-Making Model (Accounting for Sustainability, 2010) 138

7.2 Market-Based Approach Model 142

7.3 Drivers and Obstacles of CSR in the Middle East (Vinke and El-Khatib, 2011) 151

8.1 Challenges to University-Community Partnerships 163

8.2 The AUB Neighborhood Initiative 169 


\section{Boxes}

5.1 Saudization/Nitaqat System

5.2 The Work and Employment of Ethnic Minorities in Lebanon

5.3 Hay Group Compensation Report, 2011

5.4 The Economist's Employee Engagement Paper, 2010

5.5 The Profile of Assad Said Corporation (ASC), KSA

5.6 The Profile of Window Cleaning Company (WCC), Lebanon 


\section{Acknowledgments}

We have been reflecting for some time on preparing a volume describing the evolution and dynamics of corporate social responsibility (CSR) in the Middle East, given the scarce knowledge base pertaining to this topic. After much reflection and introspection, we decided to embark on the journey of compiling a book that provides a better understanding of CSR and its peculiarities and manifestations across the region. However, this effort would not have been possible had it not been for Palgrave Macmillan's keen interest in the topic, and the positive and continuous reinforcement and support provided by Virginia Thorp and her team.

We sincerely thank the World Health Organization, the World Business Council for Sustainable Development, the SMAP Clearing House, the Prince's Accounting for Sustainability Project, the Institute of Chartered Accountants in England and Wales, and the Institute for Behavioral and Applied Management for their permission to reproduce certain tables and figures in this book. Their cooperation has enabled us to build and expand upon leading knowledge in the area of CSR.

The book has also benefited from the support of colleagues and friends at the American University of Beirut. To start with, we would like to express our most sincere thanks and gratitude to our graduate student, Charissa Lloyd, who has been helping us in this project from day one. Her meticulous and professional assistance every step of the way has not gone unnoticed, and she deserves praise and appreciation for that. We should also acknowledge the help of our other graduate students, particularly Liya Kreidie and Amy Walburn, who have been very vigilant and involved in editing and formatting issues in the various phases of the compilation of this project. We owe a debt of gratitude for their gracious help and support.

As with any edited volume, the most sincere thanks are extended to the authors of the chapters. We have been fortunate to work with a very committed selection of authors from countries across the Middle 
East, including Jordan, the UAE, Egypt and Lebanon. They have been generous with their time and effort, not only providing interesting and relevant material, but also revising and re-drafting their respective chapters in response to numerous reviewer comments. They have shown an unwavering commitment to see the book through to completion and to the cause of advancing knowledge in this important area of research. Without their commitment and perseverance, this book would certainly not have been possible. 


\section{Contributors}

Malyuba Abu-Daabes is assistant professor at the German Jordanian University. She obtained a BSc in chemical engineering from the University of Jordan in 1998 and a $\mathrm{PhD}$ in chemical engineering from the University of Cincinnati, USA, in 2005. Her core research competencies are in the architecture of advanced nano-structured materials for adsorption in environmental applications, trace metal speciation in air pollution, adsorption fundamentals and separation, and membrane separation and desalination.

Akram Al Ariss is a professor of human resource management at Toulouse Business School. He is also a visiting professor at the London School of Economics and is affiliated with Pennsylvania State University, where he lectures on international human resources management (IHRM) and employment relations. He holds a PhD from Norwich Business School, University of East Anglia, UK. Akram is interested in researching and teaching IHRM and has written book chapters, journal articles and book reviews on HRM in journals such as Academy of Management Learning and Education and British Journal of Management. He is the co-author (with Dessler) of the textbook Human Resource Management, Arab World Edition. He serves on the editorial boards of Journal of World Business and Equality, Diversity, and Inclusion.

Akram has experience in management consultancy and training in multinational organizations across Europe and the Arab region. He has consulted for organizations including Projacs (Arab Middle East), Alcatel (Paris), Assad Said Corporation (Kingdom of Saudi Arabia), RATP (Paris) and the Federal Demographic Council (United Arab Emirates). He was head of the HRM Department at Champagne School of Management (France) for three years until early 2012. He was also a visiting researcher at Brunel Business School in London in 2011. 
Joseph Antoun is the President and CEO of Health System Reform SAL, a boutique advisory aimed at improving public health through health policy and health system management; the Co-director of the Center for Health Policy at the University of Chicago, where he teaches Health Systems and Pharmaceutical Policy; a professor of health policy at the Buck Institute in California; and a visiting fellow at the Department of Social Policy at the London School of Economics and Political Science. He has a master's in public policy from Harvard University and has completed health system financing and management studies at Johns Hopkins University. He obtained his doctorate in medicine and master's in medical and biological sciences at Saint Joseph University. His recent work, teaching and publications focus on health systems and systems reform, on leadership and new public management in healthcare, on rewarding healthcare innovation and on increasing access to medicines.

Tonnie Choueiri is currently Outreach Coordinator of the American University of Beirut (AUB) Neighborhood Initiative. She has an MSc in development studies from Copenhagen Business School and has worked in non-governmental organizations as well as private and educational institutions, in Denmark and Lebanon. Her main interests are in social, economic and community development.

Marian Eabrasu is a professor at the Champagne School of Management, Troyes, France, where he teaches ethics and economics. He has previously been an assistant professor at the Paris VIII University (Saint-Denis, France), and a research fellow at the International Centre for Economic Research (Turin, Italy). His research interests cover three main areas: corporate social responsibility (good practices in CSR, ISO 26000, tax evasion), moral philosophy (theories of justice, libertarianism), and economic theory and policy (subjective theory of value, normative economics). The results of his research are available in several international peer-reviewed journals and book chapters. In 2011, he co-authored an article entitled 'The Ethics of Tax Evasion', published in the Business and Society Review (vol. 116, no. 3, pp. 375-401); he is the author of a book chapter entitled 'Towards a Convergence of the Ethics of Tax Evasion and Secession' in Robert McGee (ed.), The Ethics of Tax Evasion in Theory and Practice (pp. 107-125); and he received the prize for the best developmental 
paper in CSR at the 25th conference of the British Academy of Management, for the paper: 'A Moral Pluralism Perspective on Corporate Social Responsibility'.

Aida El-Khatib currently works as a laboratory teaching assistant at the American University of Sharjah, UAE, and is in the process of attaining her MBA. She is interested in sustainability and its role in transforming business models. She holds a BBA with a concentration in accounting and finance. Her past engagements include working as an assistant relationship manager at a Standard Chartered Bank branch in the UAE, as well as working as an analyst on real-estate projects in the UAE.

David L. Haskell serves as founding President and CEO of Dreams InDeed, an international development network that strengthens indigenous social entrepreneurs in hard places to enable the poor to thrive. He has three decades of experience ranging from blended value business to venture philanthropy, launching six successful Middle Eastern start-ups and directing four East African turnarounds. As the founding Regional Director of Habitat for Humanity in the Middle East and East Africa, he doubled its impact to 2400 families housed a year. A Harvard Pforzheimer Fellow and University of Jordan Fulbright Scholar, David received an Outstanding Teaching Award from UCLA. He has presented at the business or graduate schools of AUB, Adelphi, UC Berkeley, Harvard, Notre Dame, Oxford, Princeton, Stanford, Tufts and Wheaton. He also co-authored Spiritual Resources for Change in Hard Places: A Values-Driven Social Entrepreneurship Theory of Change (2009). David earned his master's in public administration from Harvard, specializing in leadership, negotiation, mediation and conflict resolution; his master's in applied linguistics from UCLA; and his BA in communications magna cum laude from Wheaton.

Janice Hayashi Haskell serves as founding Vice-President for Program Development at Dreams InDeed, an international development network that strengthens indigenous social entrepreneurs in hard places to enable the poor to thrive. She weaves values-aligned networks, fosters social innovation and applies adaptive evaluation approaches to strengthen indigenous social entrepreneurs. Currently at work in challenging pockets of the Arab World and South-east Asia, 
she has 30 years of experience in social development and leadership coaching in the Middle East, Africa, Asia and the USA. Janice co-authored Spiritual Resources for Change in Hard Places: A ValuesDriven Social Entrepreneurship Theory of Change (2009) and authored Globalization and Migration: the Perspective of the Child (1997). She earned her master's in international affairs from Tufts Fletcher School of Law and Diplomacy; her master's in education summa cum laude from Portland State University; and her BA in psychology cum laude from Lewis and Clark.

Muna Y. Hindiyeh obtained her $\mathrm{PhD}$ in environmental engineering from Newcastle University, UK, in 1995. She has more than 20 years of experience in water and wastewater microbiology and environmental health. She received the Arab Award for the Sheikh Abdallah Al-Mubark Al-Subah for Scientific Research at the second level for the Arab World Level. She was appointed as assistant professor at the Environmental and Water Engineering Department of the German Jordanian University in 2008. Muna has much experience in social and environmental responsibility and was appointed Head of the National Mirror Committee regarding social responsibility guideline ISO 26000. She has conducted training courses, organized conferences, and been a keynote speaker on social and environmental responsibility at many conferences in the region, and issued a report entitled 'Corporate Environmental Responsibility in Jordan' supported by the United Nations Development Programme. She had been a board member of the Jordanian Institution for Standardisation and Meteorology, Jordanian Sustainable Development Society, Friends of Earth Society, Darat Shama for Elderly People and the Cultural Youth and Children Society, and she is also founder of the International Alliance for Women and Water and the National Environmental Media Society. She has participated in many national committees, such as the Lower House of Parliament, National Health Strategy and Environmental National Information, in addition to the Water Consumption Reduction Concept Committee for national school curriculums and Water Safety Plan. She has been a member in the Arab Family committee at the Arab Countries League. She also serves with national and international development organizations, such as the World Health Organization, UNDP and the US Agency for International Development (USAID). 
Dima Jamali is a professor in the School of Business at AUB and chair of the Management, Marketing and Entrepreneurship Track. She holds a PhD in social policy and administration from the University of Kent at Canterbury, UK. Her research/teaching revolves primarily around CSR. She is the author of more than 40 international publications focusing on different aspects of CSR in the Middle East, all appearing in highly reputable journals, including British Journal of Management, Corporate Governance: An International Review, Journal of Business Ethics and Business Process Management. Her research record has won her a number of scientific awards and honors, including the Abdul Hameed Shoman Award for Best Young Arab Researcher for the year 2010, Best Paper Awards at the Irish Academy of Management (2011) and the American Academy of Management (2008), British Academy of Management Fellowship for South Asia and Middle East (2007), and the Best Paper Award by the North American Case Research Association (2003). She has worked as an expert consultant for the United Nations on social policy and CSR as well as various projects funded by the World Bank, USAID, NGOs and other local public and private firms.

Sari Kassis is a trade unionist who is working hard to spread the practice of collective bargaining to any and all businesses or organizations he works with or happens to pass. While he works to organize workers into reclaiming their workplace, he also serves as a director on the board of Locrete Holdings Limited, a Palestinian company with a patented low-cost building system, and he is working on the expansion of Q perspective - a specialized consulting firm that offers, among other things, comprehensive CSR solutions to corporations into the Lebanese market. Sari is currently putting his studies in political economics at the University of Sydney to good use by getting involved in projects that join together social and political activism with sustainable, long-term plans to try to change the world for the better at the expense of those who can afford it and in favor of those who need it.

Yazan Majaj is an expert in sustainable human development with more than ten years' experience in designing and implementing CSR programs and activities in Jordan and the Middle East. Having worked in the private sector immediately after graduating from AUB 
in 2000, he moved to the regional office of the United Nations Development Fund for Women (previously UNIFEM, now UN Women) as a project manager for Economic Empowerment Projects until he eventually came to manage the regional Economic Security and ICT Programme in the Arab Region. In 2008, he and several of his team left UNIFEM and started Q perspective, a specialized consulting firm that offers comprehensive CSR solutions to corporations as part of its services. Since then, the company has designed and managed CSR, social investment and philanthropic projects and programs for leading companies in Jordan. Majaj dedicates time and effort to voluntary work and serves as a consultant, pro bono, for several NGOs based in Jordan. He is a strong advocate of food security, employability and educational efforts directed in underprivileged communities of youth, refugees and women. He graduated from AUB with a degree in psychology and completed his master's in international business at the New York Institute of Technology through a program offered through the Jordan University of Science and Technology.

Cynthia Myntti is a professor of public health practice at AUB. She received her MA in anthropology from AUB in 1974, before going on to do a PhD in social anthropology at the London School of Economics (1983) and a master's in public health from Johns Hopkins University (1986). She worked as a program officer in the Ford Foundation offices in Cairo and Jakarta for nearly a decade, and held teaching positions at Sanaa University in Yemen, the London School of Hygiene and Tropical Medicine and the University of Minnesota in the USA. In 1998 she returned to AUB as a visiting associate professor in the Faculty of Health Sciences. After publishing Paris along the Nile: Architecture in Cairo from the Belle Epoque (1999) she decided to return to graduate school, in architecture, graduating with an M Arch from Yale in 2004. Since 2006 she has directed the Neighborhood Initiative at AUB.

Jessica Jinju Pottenger provides executive support for the Middle East regional office of Dreams InDeed, an international development network that strengthens indigenous social entrepreneurs in hard places to enable the poor to thrive. She supports program development, designs management information systems, develops training materials, and coordinates international communications and social 
media networks. She previously served in China and North Korea as an editor for the NGO Citizens' Alliance for North Korean Human Rights, publishing the briefing reports 'Homecoming Kinsmen or Indigenous Foreigners?', 'The Case of North Korean Re-settlers in South Korea', 'The Battered Wheel of the Republic: NKHR Briefing Report on Violence against Women in North Korea' and 'Flowers, Guns, and Women on Bikes: NKHR Briefing Report on the Situation of Women's Rights in the DPRK'. Jessica earned her BA magna cum laude from the Woodrow Wilson School of Public and International Affairs at Princeton University.

Haitham E. Salti holds a BSc in chemical-pharmaceutical engineering from the German Jordanian University, 2010. He started his career at Arab Pharmaceutical Manufacturing (Hikma PLC) by co-initiating a project that tackled corporate environmental responsibility in the Jordanian pharmaceutical industry through applying the cleaner production approach. This study, which was the first of its kind in the region, resulted in identifying several environmentally friendly options for both case companies, thereby contributing to significant savings. He led the 'Lean Manufacturing' initiative, which focuses on eliminating waste through creating standardized processes requiring less human effort, less capital and less time to make products at a lower cost and with much fewer defects. He recently joined the MENA Process Improvement \& Technology Transfer Department at Hikma Corporate.

Yusuf Sidani is an Associate Professor of Management at the Suliman Olayan School of Business at the American University of Beirut. His articles appeared in such journals as the Journal of Business Ethics, Journal of Social Psychology, Business and Society Review and Gender in Management: An International Journal.

Alexandra Tarazi graduated with a BA in political science from AUB in 2007. She then decided to pursue a career in the non-profit sector, working in several NGOs abroad and in Lebanon on issues as diverse as children's rights, environmental awareness and women's empowerment. In 2012 she received an MA in Applied human rights from the University of York, with a dissertation on corporate responsibility in SMEs in Lebanon. Upon graduation, she continued her 
academic journey, working as a research assistant for AUB's CSR initiative on the evolution of CSR and social entrepreneurship in countries across the Middle East.

Jeannette Vinke is a senior lecturer at the American University of Sharjah. She is interested in sustainability and integrated reporting by research, training and consulting. She is currently researching the state of integrated reporting in the Gulf Cooperation Council. Jeannette is an advisory board member of the Institute of Chartered Accountants in England and Wales. Her past engagements at Deutsche Bank included leading the Cash Equities Finance team for Germany, and later, as CFO for MENA, she was one of the bank's architects in entering the region, with responsibility for setting up entities in Dubai, Abu Dhabi, Riyadh, Bahrain, Algiers, Cairo and Qatar. She has also held senior positions with KPMG in Europe and the Middle East, dealing with a variety of industries. Her portfolio in the Middle East included HSBC, Commercial Bank of Dubai and Panasonic. Her SME activities include organizing and negotiating a buyout of the Dubai-based company AME Info as the company's CFO. 


\section{Abbreviations and Acronyms}

$\begin{array}{ll}\text { A4S } & \text { Accounting for Sustainability } \\ \text { AARP } & \text { American Association of Retired Persons } \\ \text { API } & \text { active pharmaceutical ingredient } \\ \text { ATM } & \text { access to medicines } \\ \text { AUB } & \text { American University of Beirut } \\ \text { CAS } & \text { Central Administration of Statistics } \\ \text { CCECS } & \text { Center for Civic Engagement and Community } \\ & \text { Service } \\ \text { CDP } & \text { chronic diseases partnerships } \\ \text { CER } & \text { corporate environmental responsibility } \\ \text { CP } & \text { clean production } \\ \text { CSR } & \text { corporate social responsibility } \\ \text { DFID } & \text { Department for International Development } \\ \text { EDL } & \text { essential drug list } \\ \text { EIA } & \text { Environmental Impact Assessment } \\ \text { EPA } & \text { Environmental Protection Agency } \\ \text { ESCWA } & \text { United Nations Economic and Social } \\ & \text { Commission for Western Asia } \\ \text { ESG } & \text { Environmental, Social and Governance } \\ \text { GC } & \text { Global Compact } \\ \text { GCC } & \text { Gulf Cooperation Council } \\ \text { GRI } & \text { Global Reporting Initiative } \\ \text { GSK } & \text { GlaxoSmithKline } \\ \text { HIV/AIDS } & \text { Human Immunodeficiency Virus/Acquired } \\ & \text { Immune Deficiency Syndrome } \\ \text { HRM } & \text { human resource management } \\ \text { ICAEW } & \text { Institute of Chartered Accountants in England } \\ & \text { and Wales } \\ \text { IDF } & \text { International Diabetes Foundation } \\ \text { IFC } & \text { International Finance Corporation } \\ \text { INSEAD } & \text { Institut Européen d'Administration des Affaires } \\ \text { IPIECA } & \text { International Petroleum Industry } \\ & \text { Environmental Conservation Association } \\ \text { IRP } & \text { international reference pricing } \\ & \\ & \end{array}$




$\begin{array}{ll}\text { ISO } & \text { International Standard Organization } \\ \text { ITI } & \text { International Trachoma Initiative } \\ \text { JAPM } & \text { Jordanian Association of Pharmaceutical } \\ & \text { Manufacturers } \\ \text { JCPP } & \text { Jordan Clean Production Program } \\ \text { JD } & \text { Jordanian Dinar } \\ \text { JNEFI } & \text { Jordanian Network for Environmentally } \\ & \text { Friendly Industries } \\ \text { KKRCA } & \text { King Khalid Responsible Competitiveness Award } \\ \text { KPI } & \text { Key performance indicator } \\ \text { LDC } & \text { least developed country } \\ \text { MDG } & \text { Millennium Development Goals } \\ \text { MDR-TB } & \text { multi-drug-resistant tuberculosis } \\ \text { MENA } & \text { Middle East and North Africa } \\ \text { MNC } & \text { multinational corporation } \\ \text { NCD } & \text { non-communicable disease } \\ \text { NGO } & \text { non-governmental organization } \\ \text { PRS } & \text { Pearl Rating System } \\ \text { R\&D } & \text { research and development } \\ \text { SAGIA } & \text { Saudi Arabian General Investment Authority } \\ \text { SMEs } & \text { small and medium enterprises } \\ \text { TDS } & \text { total dissolved solids } \\ \text { UNDP } & \text { United Nations Development Programme } \\ \text { UNEP } & \text { United Nations Environment Program } \\ \text { UNIDO } & \text { United Nations Industrial Development } \\ & \text { Organization } \\ \text { VC } & \text { values curriculum } \\ \text { WBCSD } & \text { World Business Council for Sustainable } \\ & \text { Development } \\ \text { WHO } & \text { World Health Organization } \\ & \end{array}$

